\title{
THE MOSS FLoRA OF Ostrov Geologov (Geologists IsLand), Maxwell Bay, King George Island, Antarctica
}

\author{
PAULO E.A.S. CÂMARA ${ }^{1,2}$, BARBARA GUEDES COSTA SILVA ${ }^{1}$, MICHELINE CARVALHO- \\ SILVA ${ }^{1,3}$ and DIEGO KNOP HENRIQUES ${ }^{1}$
}

\begin{abstract}
Summary: Located of the east coast of Fildes Peninsula, South of Ardley Island, at King George Island, Ostrov Geologov (Geologist Islands) is a small island with 0.25 miles long. It only had one plant record published so far. We have conducted extensive fieldwork on the site and provide here a comprehensive checklist and a key for the moss species occurring on the island. Despite its small size, theislandcontains about $35 \%$ of all theFildes Peninsula moss flora, six new records were found. The pristine state of the island due to its relative isolation, presence of avian nesting sites and a relatively rich moss flora are strong arguments in favor of protection status for the island.
\end{abstract}

Key words: Antarctica, Bryophyta, Fildes Peninsula, moss.

\begin{abstract}
Resumen: Flora de musgos de Ostrov Geologov (Isla de los Geologos), Maxwell Bay, King George Island, Antártica. Ubicada en la costa este de la Península Fildes, al sur de la isla Ardley en Isla 25 de Mayo, la isla del Geólogo es una pequeña isla con $0.5 \mathrm{Km}$ de extensión. Hasta ahora, solo existe un registro de planta. Hemos realizado colecciones y presentamos una lista y una clave para las especies de musgos que ocurren en la isla. Aunque de pequeño tamaño, la isla posee cerca de $35 \%$ de todas las especies de musgos que ocurren en la península Fildes y seis nuevos registros fueron encontrados. Su relativo aislamiento de los turistas es un factor que contribuye para su preservación.
\end{abstract}

Palabras clave: Antártica, Bryophyta, Fildes, musgos.

\section{INTRODUCTION}

Antarctica and its surrounding islands are considered one of the most isolated places in the world, making this continent a unique place for biodiversity and environmental studies. The South Shetlands archipelago is located north of the Antarctic Peninsula. It has cold moist maritime climate and longer snow free period when compared with the continental areas (Lewis Smith, 1984). Such conditions favor the development of vegetation (especially cryptogamic), making the South Shetlands a place rich in plant and lichen species (Ochyra et al., 2008).

\footnotetext{
1 Universidade de Brasília, Departamento de Botânica, Brasília, DF. Brasil.

2 pcamara@unb.br (Correspondingauthor)

3 Universidade Federal dos Vales do Jequitinhonha e Mucuri, Campus Unaí.
}

The King George Island is the biggest island in the South Shetlands and houses several scientific stations and field huts from different countries, making it one of the areas with more human activity in Antarctica. This is specially seen in Fildes Peninsula, situated in the southwestern portion of King George, where 5 stations and the Chilean airport are located (Peter, 2008). The Fildes region is home to several protected species and counts with two protected areas (ASPA 125 and ASPA 150). The ASPA 150 comprises the island of Ardley, located in the Maxwell Bay. Ardley harbours of an outstanding flora, with several species of lichens, mosses and vascular plants (Environment Protocol, 2009).

South of Ardley, outside the protected area, is the small island of Ostrov Geologov, translated from the Russian as Geologist Island also known as isla Catedral in Chilean toponymy. It is 0.25 miles long and approximately $78,765 \mathrm{~m}^{2}$, located just 
south of Ardley Island at Fildes Peninsula in King George Island (62'13'18'S and 58 $\left.56^{\prime} 35^{\prime \prime} \mathrm{W}\right)$ with elevations reaching up to $35 \mathrm{~m}$ above sea level.

The island is rarely visited and is not on the touristroute and of likely to contain very few science activities. Peter et al. (2008) considered its northern part as a sensitive area due to the presence of breeding sites for giant Petrels (Macronectes giganteus).

The flora of Ostrov Geologov remains largely unknown, as only one plant has been reported for the site so far: Hypnum revolutum (Mitt.) Lindb. By Ochyraet al. (2008), and a comprehensive checklist for the island is still missing.

Areas in Antarctic are always of conservation interest, and this can only be achieved by better knowledge of its flora and fauna. It is our hope that data provided here will increase this knowledge helping with future decision processes towards the conservation of this site.

In order to fill the gap in the knowledge of Ostrov Geologov's flora, an expedition was set in order to collect the mosses of the island. The plants were identified and a list of species and identification key is provided.

\section{Methods}

A field survey was carried during the summer of 2017, and samples were collected all over the area. Due to the small size of the site, only one field trip was needed. Collections were made according to Schofield (1984) and vouchers are deposited at herbarium UB - University of Brasília. Classification system follows Goffinet et al. (2009). Identifications were done with the use of proper literature (mostly Ochyra et al., 2008) using a dissecting and compound microscope. Voucher specimens are listed in table 1.

\section{Results}

Collections resulted in 89 samples, belonging to 17 species divided among 10 genera and nine families. This represents ca. $35 \%$ of the moss flora of Fildes Peninsula and ca. $15 \%$ of the known species in Antarctic (Ochyra et al., 2008). The most diverse family is Pottiaceae with two genera and five species, of which Syntrichia is the most diverse genus with three species. Most of the vegetation is being formed by big carpets of Sanionia uncinata (Hedw.) Loeske, that virtually dominates the landscape. Six new records for Fildes Peninsula and the Maxwell Bay region are reported here, marked with asterisks in the species list below.

Species list (asterisks mark new records for the Fildes region)

Amblystegiaceae

Sanionia uncinata (Hedw.) Loeske

Andreaeaceae

Andreaea gainii Cardot

Andreaea regularis Müll.Hal.

Batramiaceae

Bartramia patens Brid.

Brachytheciaceae

Brachythecium austrosalebrosum (Müll.Hal.) Kindb.

Bryaceae

Bryum argenteum Hedw.*

Bryum orbiculatifolium Cardot \& Broth.*

Bryum pseudotriquetrum (Hedw.) P.Gaertn.,

B.Mey. \& Scherb.

Ditrichaceae

Ceratodon purpureus (Hedw.) Brid.

Grimmiaceae

Schistidium andinum (Mitt.) Herzog *

Schistidium lewis-smithii Ochyra *

Hypnaceae

Hypnum revolutum (Mitt.) Lindb.

Pottiaceae

Hennediella antarctica (Ångstr.) Ochyra \& Matteri *

Hennediella heimii (Hedw.) R.H. Zander *

Syntrichia magellanica (Mont.) R.H. Zander

Syntrichia saxicola (Cardot) R.H. Zander

Syntrichia filaris (Müll.Hal.) R.H.Zander

Comments on some species distribution:

- Bartramia patens has been reported for Fildes region only once, limited to lake Kitezh region and this is the second report.

- Bryum argenteum has been reported from King George Island but not for the Fildes Peninsula or Maxwell Bay and adjacent areas. It is considered by Ochyra et al. (2008) as rare in the South Shetlands (reported only from the islands of King George (Admiralty Bay) and Deception). We 
preferred to use $B$. argenteum as sensu lato and did not differentiated between the two varieties recognized in Antarctica; we hope that DNA studies will improve our understanding of the real identity of those taxa.

- According to Ochyra et al. (2008) Bryum orbiculatifolium has not yet been reported for King George Island, but in the South Shetlands is reported only for Deception island.

- Hennediella Antarctica has been reported from King George Island but not for the Fildes Peninsula or Maxwell Bay and adjacent areas. According to Ochyra et al. (2008) it is rare but widely scattered in the South Shetlands, been reported for King George Island (Admiralty Bay, Brans field Strait, Drake Passage and Potter Peninsula), Greenwich island, Livingston island (Byers and Hurd peninsula) and Deception island.

- Hennediella heimii has been reported from King George Island but not for the Fildes Peninsula or Maxwell Bay and adjacent areas. According to Ochyra et al. (2008) it is widely distributed in the South Shetlands, with reports from Elephant, Clarence, as pland and Gibbs islands, King George Island (Admiralty Bay and Potter Cove), Livingston (Byers peninsula) and Deception islands.

- Schistidium andinum has been reported from King George Island but not for the Fildes Peninsula or Maxwell Bay and adjacent areas. According to Ochyra et al. (2008) the species is rare and only occasionally found in the South Shetlands, with reports for King George Island (Admiralty Bay), Livingston Island (Byers and Hurd Peninsula) and Deception island.

- Schistidium lewis-smithii has been reported from King George Island but not for the Fildes Peninsula or Maxwell Bay and adjacent areas. According to Ochyra et al. (2008) the species is rare and only known from two collections in King George Island (Adiralty Bay) and Livingston island (Byers peninsula).

\section{Key to the mosses of Ostrov Geologov}

1. Plants pleurocarpous.

2. Costa short and double.

Hypnum revolutum

2'. Costa single. 3

3. Leaves falcate secund. Sanionia uncinata

3'. Leaves straight. Brachythecium austrosalebrosum

1'. Plants acrocarpous. 4

4. Leaves ecostate. 5

5. Leaves lanceolate. Andreaea gainii

5 '. Leaves panduriform. Andreaea regularis

4 '. Leaves costate. 6

6. Hyaline cells present at leaf base. 7

7. Subulapresent, hyaline cells papillose. Bartramia patens

7'. Subula absent, hyaline cells smooth.

8. Laminal cells epapillose, hyaline cells occupying theen tire base.

9. Apex serrulate. Ceratodon purpureus

9'. Apex smooth.

10. Leaf margin plane.

Schistidium lewis-smithii

10 '. Leaf margin recurved or revolute. Schistidium andinum

8'. Laminal cells papillose, hyaline cells surrounded by at least one row of non hyaline ones. . 11

11. Long hyaline awn present. Syntrichia magellanica 11 '. Long hyaline awn absent. 
12. Costa excurrent. Syntrichia saxicola

12'. Costa percurrent. Syntrichia filaris

6 '. Hyaline cells absent from leaf base. 13 13. Leavesmarginal border absent or indistinct. Hennediella heimii

13 '. Leaves with distinct margin of elongate cells. 14

14. Basal leaves papillose. Hennediella antarctica 14 '. Basal leaves smooth. 15

15. Upper half of theleaf hyaline, silver. Bryum argenteum $15^{\prime}$. Upper and lower half of leaf same, green. 16

16. Leaf base red, lanceolate or oblong-lanceolate.

16 . Leaf base green, leaves orbicular. Bryum pseudotriquetrum Bryum orbiculatifolium

\section{Final Considerations}

The moss flora of Ostrov Geologov, which consists of about $35 \%$ of all mosses known from the Fildes region is quite diverse for it's size (only 0.25 miles long).

Its location, out of the interests of tourists and with few scientific studies made, has resulted in a quite undisturbed area, free of garbage and pollution, which are sometimes quite frequent in Fildes as the direct result of human occupation. Those facts as well as the presence of avian nesting sites observed on the island, makes this area an important site for preservation. It is our hope that this floristic survey will contribute to the knowledge needed for the conservation of the island.

\section{AcKnowledgments}

We are very grateful to the Brazilian Antarctic Program (PROANTAR), the Ministry of Ciência Tecnologia e Inovação and $\mathrm{CNPq}$ for providing funds. The Brazilian Navy and Air Force for providing important logistic support and Special thanks to INACH (Instituto Antarctico Chileno), and Great Wall station for all logistic support during the last field season. This study was funded by PROANTAR, CNPq call 64/2013. We also thank Dr. Melinda Waterman for her valuable support.

Table 1. Voucher information (note that is common that species grow associated causing number duplication):

Andreaea gainii: Câmara et al. 4044, 4048. Andreaea regularis: Câmara et al. 4066. Bartramia patens: Henriques et al. 217, 219, 232, 234. Brachythecium austrosalebrosum: Câmara et al. 4043. Bryum argenteum: Câmara et al. 4024, 4033, 4038, 4039, 4042. Bryum orbiculatifolium: Henriques et al. 225, 226. Bryum pseudotriquetrum: Câmara et al. 4032, 4034, 4037a, 4043, 4065. Ceratodon purpureus: Câmara et al. 4068. Hennediella antarctica: Câmara et al. 4024, 4037. Hennediella heimii: Câmara et al. 4034, 4068. Hypnum revolutum: Câmara et al. 4055, 4063a; Henriques et al. 233. Sanionia uncinata: Câmara et al. 4020, 4021, 4022, 4023, 4024, 4025, 4026, 4029, 4032, 4034, 4035, 4036, 4037, 4038, 4039, 4041, 4043, 4045, 4046, 4047, 4054, 4055, 4056, 4063. Schistidium andinum: Câmara et al. 4020. Schistidium lewis-smithii: Câmara et al. 4026, 4027, 4050, 4067, 4067. Syntrichia magellanica: Câmara et al. 4020, 4022, 4028, 4049, 4059, 4063; Henriques et al. 228. Syntrichia saxicola: Câmara et al. 4021, 4024, 4029, 4031, 4032, 4038, 4040, 4043, 4046, 4047, 4049, 4051, 4052, 4053, 4056, 4060, 4061, 4062, 4064; Henriques et al. 229, 230. Syntrichia filaris: Câmara et al. 4030, 4063; Henriques et al. 227.

\section{BIBLIOGRAPHY}

ENVIRONMENT PROTOCOL. 2009. Area Protection and Management/ Monuments. ASPA 150: Ardley Island, Maxwell Bay, King George Island (25 de Mayo): Disponibleen: http://www.ats.aq/documents/ recatt/Att427_e.pdf_[acceso, 13 mach 2017].

GOFFINET, B.,W. R. BUCK, A. J. SHAW.2009. Morphology, anatomy, and classification of the Bryophyta, pp. 55-138. In: GOFFINET, B. \&A. 
J. SHAW (eds.), Bryophyte Biology. 2nd ed. Cambridge University Press, Cambridge.

LEWIS SMITH, R. I. 1984. Terrestrial plant biology of the sub-Antarctic and Antarctic. pp. 61-162. In:LAWS, R. M. (ed.). Antarctic ecology, 1.Academic Press, London.(Harcourt Brace Jovanovich. Publishers).

OCHYRA, R., R. I. LEWIS SMITH, H. BEDNAREKOCHYRA. 2008. The illustrated moss flora of Antarctica.Cambridge University Press, Cambridge.
PETER, H. -U., C. BUESSER, O. MUSTAFA \& S. PFEIFFER. 2008. Risk assessment for the Fildes Peninsula and Ardley Island, and development of management plans for their designation as Specially Protected or Specially Managed Areas. Research Report 20313 124001155e UBA-FB. 508p.

Recibido el 3 de marzo de 2017, aceptado el 17 de mayo de 2017. 
